\title{
SUBKLONING DAN ISOLASI GEN PENYANDI MIKRONEMA 3 (MIC-3) Toxoplasma gondii ISOLAT LOKAL
}

\author{
Diana Indrasanti ${ }^{1 *}$, Aris Haryanto ${ }^{2}$ dan Wayan T. Artama ${ }^{2}$ \\ 1) Laboratorium Kesehatan Ternak, Fakultas Peternakan, UNSOED Purwokerto \\ ${ }^{2)}$ Laboratorium Biokimia, Fakultas Kedokteran Hewan, UGM, Yogyakarta \\ e-mail: dianaindrasanti@gmail.com
}

\begin{abstract}
Microneme protein (MIC) is one of proteins that belongs to excretory-secretory antigens (ESAs) of Toxoplasma gondii. Microneme 3 protein (MIC-3) is the protein that plays an important role in the invasion proccess during cell infection as a mediator attachment parasite to the host cell. The aim of this research is to clone mic3 (gene encoding for MIC-3) of $T$. gondii from local isolate using recombinant DNA technology by cloning mic3 in an expression vector. Deoxyribonucleic acid (DNA) from T. gondii tachyzoites was amplified by PuRe Taq RTG-PCR Beads using mic3 specific primers. Amplified DNA was double digested using EcoRV and HindIII restriction endonucleases and then purified using EZ-10 spin coloumn purification kit. The mic3 DNA was ligated into pET-32a(+) expression vector and transformated into Escherichia coli BL21. The results showed that recombinant mic3 gene $4.2 \mathrm{kDa}$ has been successfully performed by cloning gene encoding for MIC-3 protein of $T$. gondii local isolate into pET-32a $(+)$ and transformed to E. coli BL21.
\end{abstract}

Keywords: Toxoplasma gondii, cloning, MIC-3 protein

\section{PENDAHULUAN}

Toxoplasma T. gondii merupakan patogen obligat intraseluler yang termasuk dalam filum Apicomplexa. Parasit protozoa ini dapat menginfeksi hospes dalam kisaran yang luas, diantaranya pada burung, mamalia dan hewan liar, dengan cakupan geografi ke seluruh dunia (Black and Boothroyd, 2000). T. gondii di Indonesia tersebar luas dengan rata-rata prevalensi pada manusia sebesar 2-63\%, sedangkan pada kucing $35-73 \%$, pada anjing $75 \%$, pada babi $11-36 \%$, pada kambing 11-61\% (Gandahusada, 1995; Terazawa et al., 2003) dan pada sapi $18,33 \%$ (Wihadmadyatami, 2009).

Infeksi $T$. gondii pada individu imunokompeten bersifat ringan dan tidak menimbulkan gejala klinis, sebaliknya infeksi T. gondii pada individu immunocompromise kemungkinan berakibat fatal. Gejala yang terlihat antara lain: lesu, lelah, sakit kepala, nyeri otot dan sendi, karena gejalanya mirip dengan gejala penyakit lain, misalnya flu, toksoplasmosis menjadi tidak terdeteksi. Kecurigaan mulai muncul bila gejala klinis sudah menunjukkan adanya pembesaran kelenjar limfa (Gandahusada, 1995). Penyakit ini dapat menjadi fatal pada individu imunosupresi, misalnya penderita acquired immunodeficiency syndrome (AIDS) karena dapat menimbulkan kematian. Pada ibu hamil yang terinfeksi $T$. gondii, dapat berakibat fatal pada bayi yang dikandungnya karena dapat menyebabkan abortus, lahir mati, kebutaan, retardasi mental, ensefalitis dan beberapa kelainan neonatal.

Pengobatan yang saat ini dianjurkan, ditujukan untuk pengobatan spesifik dan efektif terhadap takizoit $T$. 
gondii, sedangkan bradizoit dalam kista jaringan tidak dapat dimusnahkan, sehingga obat-obat ini hanya dapat memberantas infeksi akut saja, namun tidak dapat menghilangkan infeksi kronis (Gandahusada, 1995; Carruthers, 2004). Pengobatan tersebut juga mempunyai adanya beberapa kekurangan, yaitu reaksi alergi, efek samping (toksik), khususnya pengobatan jangka panjang bagi penderita AIDS maupun bagi wanita hamil. Oleh karena itu, penelitian tentang pencegahan dan pengobatan toksoplasmosis kiranya penting untuk dilakukan.

Penelitian mengenai antigen rekombinan telah dilakukan oleh Beghetto, et al. (2003; 2005), dan Buffolano, et al. (2005). Protein mikronema (MIC-3) termasuk dalam antigen ekskretori sekretori $T$. gondii (ESA) yang diduga merupakan kandidat vaksin yang poten dan efektif terhadap toxoplasmosis, karena berperan dalam proses adhesi $T$. gondii pada sel hospes (Ismael, et al., 2003; Beghetto, et al., 2005; Buffolano, et al., 2005). Kloning dan ekspresi gen penyandi protein MIC-3 isolat RH telah dilakukan, serta menunjukkan kemampuan memacu respon imun yang kuat untuk proteksi terhadap infeksi $T$. gondii pada hewan coba (Ismael et al., 2003). Pada penelitian ini telah dilakukan subkloning gen penyandi protein MIC-3 pada vektor ekspresi pET-32a(+) dan ditransformasi ke dalam hospes E. coli BL21. Protein rekombinan diharapkan dapat terekspresikan yang selanjutnya dapat digunakan sebagai kandidat vaksin maupun perangkat diagnosis toksoplasmosis.

\section{METODE PENELITIAN}

Penyiapan DNA insert mic3 dan vektor ekspresi

Amplifikasi DNA insert mic-3 menggunakan PCR (Polymerase Chain Reaction)
DNA takizoit $T$. gondii diperoleh dari Pusat Antar Universitas (PAU) UGM, Yogyakarta. Insert mic-3 diperoleh dengan mengamplifikasi DNA takizoit menggunakan primer spesifik. Primer spesifik untuk gen penyandi protein MIC-3 yaitu primer forward M3F3: 5 , GTGTGATATCCTTGTCCAACACTG GGTA 3' dan primer reverse M3R3: 5' CACGAAGCTTTGCGAATGGGCG 3' diencerkan terlebih dahulu sehingga konsentrasi kedua primer tersebut menjadi $10 \mathrm{pmol} / \mu \mathrm{l}$. Pencampuran komponen reaksi untuk proses amplifikasi dilakukan dengan penambahan komponen-komponen ke dalam puRe Taq RTG-PCR sebagai berikut: $2 \mu \mathrm{l}$ template DNA insert (280 $\mathrm{ng} / \mu \mathrm{l}), 2 \mu \mathrm{l}$ primer M3F3 (10 pmol/ $\mu \mathrm{l})$, dan $2 \mu \mathrm{l}$ primer M3R3 (10 pmol/ $\mu \mathrm{l})$ serta $19 \mu \mathrm{ldd} \mathrm{H}_{2} \mathrm{O}$ (aquabidest) filter sehingga total volume menjadi $25 \mu \mathrm{l}$. Tabung mikro $0,2 \mathrm{ml}$ yang berisi campuran reaksi tersebut dimasukkan ke dalam thermocycler dan diamplifikasi dengan program sebagai berikut: (1) denaturasi pertama dengan suhu $94{ }^{\circ} \mathrm{C}$ selama 5 menit, (2) denaturasi $94{ }^{\circ} \mathrm{C}$ selama 1 menit, (3) annealing primer $60{ }^{\circ} \mathrm{C}$ selama 1 menit, (4) polimerisasi $72{ }^{\circ} \mathrm{C}$ selama 1 menit, (5) siklus diulang sehingga total siklus 35 kali, dan (7) diakhiri dengan polimerisasi tambahan pada suhu $72{ }^{\circ} \mathrm{C}$ selama 5 menit. Hasil amplifikasi selanjutnya dielektroforesis pada gel agarosa $1 \%$.

\section{Pemotongan DNA dan pET-32a(+) dengan restriksi endonuklease}

Deoxyribonucleic acid hasil amplifikasi (untuk insert mic3), pWTAM3 $(1850 \mu \mathrm{g} / \mathrm{ml})$ (sebagai kontrol) dari penelitian sebelumnya (Dewi, 2006) dan pET-32a(+) (50 $\mathrm{ng} / \mu \mathrm{l})$ dipotong menggunakan endonuklease restriksi HindIII dan EcoRV dengan campuran reaksi sebagai berikut: $5 \mu \mathrm{l}$ DNA, $1 \mu \mathrm{l}$ enzim HindIII $(10 \mathrm{U} / \mu \mathrm{l}), 1 \mu \mathrm{l}$ enzim 
EcoRV (10 U/ $\mu \mathrm{l}), 1 \mu \mathrm{l} 10 \mathrm{x}$ buffer enzim,

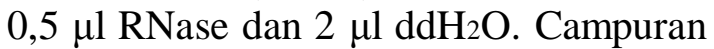
reaksi diinkubasi pada waterbath suhu 37 ${ }^{\circ} \mathrm{C}$ selama 1-2 jam.

\section{Elektroforesis DNA}

Elektroforesis

DNA

menggunakan gel agarosa $1 \%$ yang dibuat dengan cara menimbang agarosa 0,4 gram, ditambahkan $40 \mathrm{ml}$ buffer elektroforesis (TBE atau TAE 1X), kemudian dilarutkan dalam microwave dan dalam keadaan hangat-hangat kuku ditambahkan ethidium bromide $\left(\mathrm{C}_{21} \mathrm{H}_{2} \mathrm{ON} \mathrm{N}_{3} \mathrm{Br} ; 2\right.$, 2, diamino-10-ethyl-9phenyl- henanthridinium bromide; homidium bromide) dan dipindahkan ke gel tray yang telah dipasang sisiran untuk membuat sumuran. Gel yang terbentuk dimasukkan ke dalam tangki elektroforesis, kemudian dituangkan buffer elektroforesis sampai gel terendam. Sampel DNA dicampurkan dengan $2 \mu 1$ DNA loading buffer di atas parafilm kemudian dimasukkan ke dalam sumuran gel dengan hati-hati, selanjutnya elektroforesis dilakukan dengan tegangan 100 volt, sampai migrasi loading buffer mencapai bagian ujung gel. Hasil elektroforesis divisualisasi dengan $U V$ transilluminator.

Purifikasi DNA insert mic3 dengan EZ10 spin coloumn purification kit

Pita DNA dalam gel dipotong dengan pisau yang tajam dan bersih. Berat potongan gel ditimbang dan dimasukkan dalam microtube $1,5 \mathrm{ml}$. Binding buffer II sebanyak $400 \mu \mathrm{l}$ ditambahkan untuk masing-masing 100 mg dari berat gel, sedangkan untuk konsentrasi gel yang tinggi (1,5-2,0\%), $700 \mu \mathrm{l}$ Binding buffer II ditambahkan untuk masing-masing $100 \mathrm{mg}$ dari berat gel. Inkubasi dilakukan pada suhu 50-60 ${ }^{\circ} \mathrm{C}$ selama 10 menit sampai agarose larut seluruhnya. Campuran diatas dimasukkan ke dalam coloumn EZ-10 dan dibiarkan berdiri selama 2 menit. Sentrifus dilakukan selama 2 menit, $10.000 \mathrm{rpm}$. Cairan pada tabung dibuang dan ditambahkan $500 \mu \mathrm{l}$ wash solution pada coloumn EZ-10. Sentrifus kembali selama 1 menit, 10.000 rpm. Cairan pada tabung dibuang. Langkah sebelumnya diulang kembali, namun sentrifus dilakukan selama 2 menit. Coloumn diletakkan dalam microtube bersih $1,5 \mathrm{ml}$ dan ditambahkan 30-50 $\mu$ l elution buffer pada pusat kolom. Inkubasi dilakukan selama 2 menit. Coloumn disentrifus selama 2 menit, $10.000 \mathrm{rpm}$ untuk mengelusi DNA, selanjutnya DNA yang didapat dalam microtube disimpan pada $20^{\circ} \mathrm{C}$

\section{Pengukuran konsentrasi DNA}

Konsentrasi DNA diukur dengan melakukan pengenceran DNA 50 kali dengan cara mencampur $2 \mu \mathrm{l}$ DNA dengan $98 \mu \mathrm{l}$ aquades, kemudian diukur optical density (OD) menggunakan spektrofotometer dengan panjang gelombang $260 \mathrm{~nm}$. Konsentrasi DNA dihitung menggunakan rumus:

Absorbansi OD260 x pengenceran x 50

\section{Kloning gen insert ke dalam vektor ekspresi}

Ligasi dengan vektor pET 32a(+)

Sebanyak $1 \mu \mathrm{l}$ pET-32a(+)(50 $\mathrm{ng} / \mu \mathrm{l}), 3 \mu \mathrm{l}$ DNA insert untuk mic3 (615 ng/ $\mu \mathrm{l}$ dan $1 \mu \mathrm{l}$ insert untuk mic3' (105 $\mathrm{ng} / \mu \mathrm{l}), 1 \mu \mathrm{l}$ T4 DNA ligase (3U/ $\mathrm{ll}), 2 \mu \mathrm{l}$ buffer T4 DNA ligase dan $3 \mu 1$ nuklease free water dicampurkan dalam satu tabung. Campuran reaksi diinkubasi pada suhu $16^{\circ} \mathrm{C}$ selama semalam.

\section{Pembuatan ultra-competent E. coli BL21 (Inoue method)}

E. coli BL21 diinkubasi menggunakan shaker dengan suhu $37{ }^{\circ} \mathrm{C}$ selama semalam dalam media LB. Kultur kemudian diinokulasi ke dalam $250 \mathrm{ml}$ media SOC, menggunakan shaker dengan 
suhu $37{ }^{\circ} \mathrm{C}$ hingga nilai $\mathrm{OD}_{600} \sim 0,6$. Kultur disimpan didalam es selama 10 menit, selanjutnya disentrifugasi selama 10 menit, $3000 \mathrm{rpm}$, dengan suhu $4{ }^{\circ} \mathrm{C}$. Sel diresuspensi perlahan dalam $80 \mathrm{ml}$ TB (transformation buffer) dingin dan disimpan didalam es selama 10 menit, selanjutnya disentrifugasi kembali selama 3000 rpm 10 menit pada suhu $4{ }^{\circ} \mathrm{C}$. Kultur diresuspensi kembali dengan 20 ml TB dingin, kemudian ditambahkan DMSO (dimethylsulfoxide) hingga konsentrasi akhir menjadi 7\% atau gliserol hingga konsentrasi akhir $25 \%$. Kultur disimpan di dalam es selama 10 menit. Aliquot dipindahkan ke tabung microtube 1-2 $\mathrm{ml}$ dan disimpan pada suhu $-80{ }^{\circ} \mathrm{C}$.

\section{Transformasi dengan teknik heat shock}

Tabung yang berisi bakteri kompeten E. coli BL21 sebanyak $100 \mu \mathrm{l}$ ditambah dengan $10 \mu \mathrm{l}$ plasmid yang sudah diligasi dengan DNA sampel, kemudian dicampur dengan baik, dan diinkubasi dalam es selama 30 menit, selanjutnya dilakukan heat shock pada waterbath $42 \quad{ }^{\circ} \mathrm{C}, 90$ detik. Hasil transformasi dimasukkan ke dalam es secara cepat selama 1-2 menit, selanjutnya ditambahkan $800 \mu \mathrm{l}$ SOC. Kultur kemudian diinkubasi dalam shaker $37{ }^{\circ} \mathrm{C}$ selama 1 jam dan siap ditanam pada plate agar LB.

\section{Penanaman pada plate LB agar}

Kultur hasil proses transformasi ditumbuhkan pada plate agar LB yang telah ditambahkan ampisilin $25 \mathrm{mg} / \mathrm{ml}$. Plate agar LB yang telah ditanami kemudian diinkubasi dalam inkubator suhu $37^{\circ} \mathrm{C}$. Hasil pertumbuhan bakteri berupa koloni bening keputihan dianalisis lebih lanjut.

\section{Isolasi plasmid dengan metode lisis alkali}

Media LB cair yang mengandung koloni plasmid rekombinan hasil biakan dituang ke microtube sampai hampir penuh $(1,5 \mathrm{ml})$, kemudian disentrifugasi pada 12.000 rpm selama 30 detik dan supernatan dibuang. Pelet diresuspensi dengan $100 \mu \mathrm{l}$ lysing solution I dan ditambahkan $200 \mu \mathrm{l}$ lysing solution II, dicampur dengan cara membolakbalikkan tabung secara cepat sebanyak 5 kali. Seratus lima puluh microliter lysing solution III ditambahkan dan divortek selama 10 detik. Larutan diletakkan dalam es selama 5 menit dan selanjutnya disentrifus dengan kecepatan $12.000 \mathrm{rpm}$ selama 5 menit. Supernatan dipindahkan ke dalam tabung baru dan ditambahkan fenol:kloroform isoamil alkohol (CIAA) $1: 1$, dan dicampur menggunakan vortek. Sentrifus kembali selama 5 menit, kecepatan 12.000 rpm. Fase atas dipindahkan ke microtube baru dan ditambahkan 2x volume etanol absolut dingin. Presipitasi dilakukan pada suhu $20^{\circ} \mathrm{C}$ selama 1 jam, kemudian disentrifus dengan kecepatan $12.000 \mathrm{rpm}$ selama 5 menit. Pelet dibilas dengan etanol $70 \%$, dikeringanginkan dan diresuspensi dengan TE (Tris EDTA).

\section{HASIL DAN PEMBAHASAN}

Kloning gen melalui pendekatan metode PCR memungkinkan untuk mendapatkan klon yang membawa gen spesifik yang diinginkan (Garcia- Réquet et al., 2000; Sambrook and Russel, 2001; Dewi, 2006). Sekuen primer forward dan reverse yang digunakan dalam penelitian ini dapat dilihat pada Gambar 1.

Primer M3F3 dirancang sedemikian rupa sehingga mengandung sisi pemotongan EcoRV dan M3R3 mengandung sisi pemotongan HindIII. Pemotongan DNA hasil amplifikasi dan vektor pET-32a(+) (Gambar 2) dilakukan dengan enzim restriksi endonuklease EcoRV dan HindIII. Pemotongan ini dimaksudkan untuk membuat kedua ujung DNA insert mic3 kompatibel dengan ujung vektor pET-32a(+) yang memungkinkan penggabungan keduanya 
menggunakan T4 DNA ligase (Gambar $3)$.

\begin{tabular}{|l|} 
Primer Forward M3F3 \\
5'GTGTGATATCCTTGTCCAACACTGGGTA 3' \\
EcoRV site \\
Primer Reverse M3R3 \\
5'CACGAAGCTTTGCGAATGGGCG 3' \\
HindIII site
\end{tabular}

Gambar 1. Sekuen primer M3F3 dan M3R3 serta sisi restriksinya.

Penelitian dengan urutan primer yang sama namun dengan sisi pemotongan yang berkebalikan yaitu HindIII pada forward primer (M3F1) dan EcoRV pada reverse primer (M3R1) telah berhasil dilakukan oleh Ismael et al. (2003) dan peneliti sebelumnya, Dewi (2006).

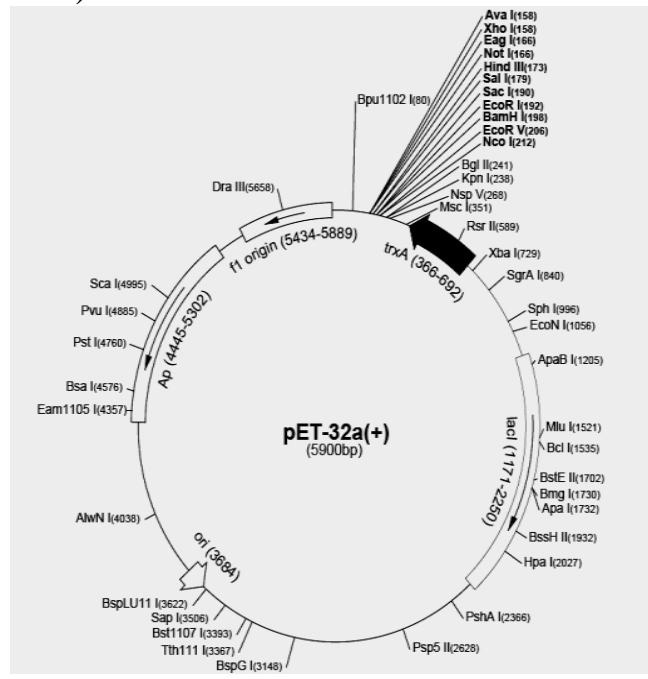

Gambar 2. Skema vektor ekspresi pET32(+) (Novagen, 2006)

Ismael et al. mengamplifikasi gen penyandi MIC-3 isolat $\mathrm{RH}$ dan diligasi ke dalam pBluescript II SK, diperoleh amplikon sebesar 1155 bp. Dewi (2006) mengamplifikasi gen penyandi MIC-3 isolat lokal (1200 bp) dengan program yang sama dan diligasi pada pGEM-T
(3000 bp), diperoleh amplikon sebesar 4200 bp. Hasil amplifikasi DNA takizoit $T$. gondii menggunakan primer spesifik untuk gen mic3 dapat dilihat pada Gambar 4.

Transformasi DNA rekombinan ke dalam Escherichia coli BL21 dilakukan dengan teknik heat shock (Sambrook and Russel, 2001) untuk memindahkan DNA rekombinan hasil ligasi ke dalam hospes yang kompeten, dalam hal ini adalah E. coli BL21. Bakteri kompeten diperoleh dengan perlakuan $\mathrm{CaCl}_{2}$ dingin. Transformasi dilakukan secara efektif pada suhu $42{ }^{\circ} \mathrm{C}$ selama 90 detik (Glick and Pasternak, 1994; Sambrook and Russell, 2001). Mekanisme transformasi yang melibatkan $\mathrm{CaCl}_{2}$ dan panas diduga merusak dinding sel bakteri pada lokasi tertentu yang memudahkan plasmid masuk ke dalam bakteri (Glick and Pasternak, 1994).

Hasil transformasi selanjutnya dikultur pada plate agar LB, yang mengandung ampisilin, untuk seleksi. Hasil transformasi menunjukkan adanya 1 koloni putih (Gambar 5). Jumlah koloni putih yang diduga koloni rekombinan tersebut sangat sedikit. Pada tingkat sel, ekspresi gena yang diklon mungkin berpengaruh merugikan bagi hospes, bahkan jika produk translasi itu sendiri tidak toksik. Aliran energi dan molekul yang diakibatkan oleh ekspresi cepat gena yang diklon dapat menimbulkan kerugian pada bakteri rekombinan dalam hal pengurangan laju pertumbuhan sel dan penurunan stabilitas sel, bila dibandingkan dengan sel nonrekombinan serta kemungkinan berakibat perubahan morfologis seperti peningkatan kerapuhan sel (Brown, 1991; Old and Primrose, 2003). 


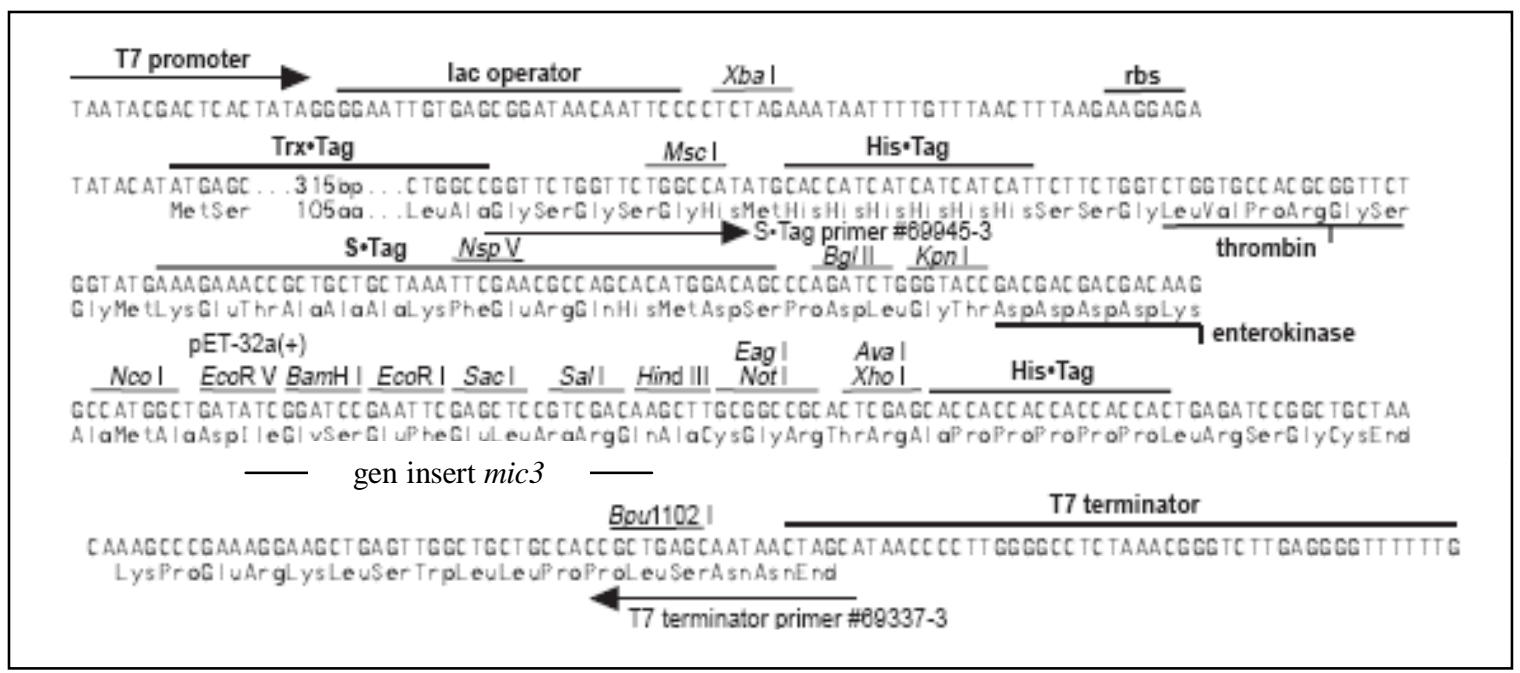

Gambar 3. Skema letak gen insert mic3 di dalam pET-32a(+)

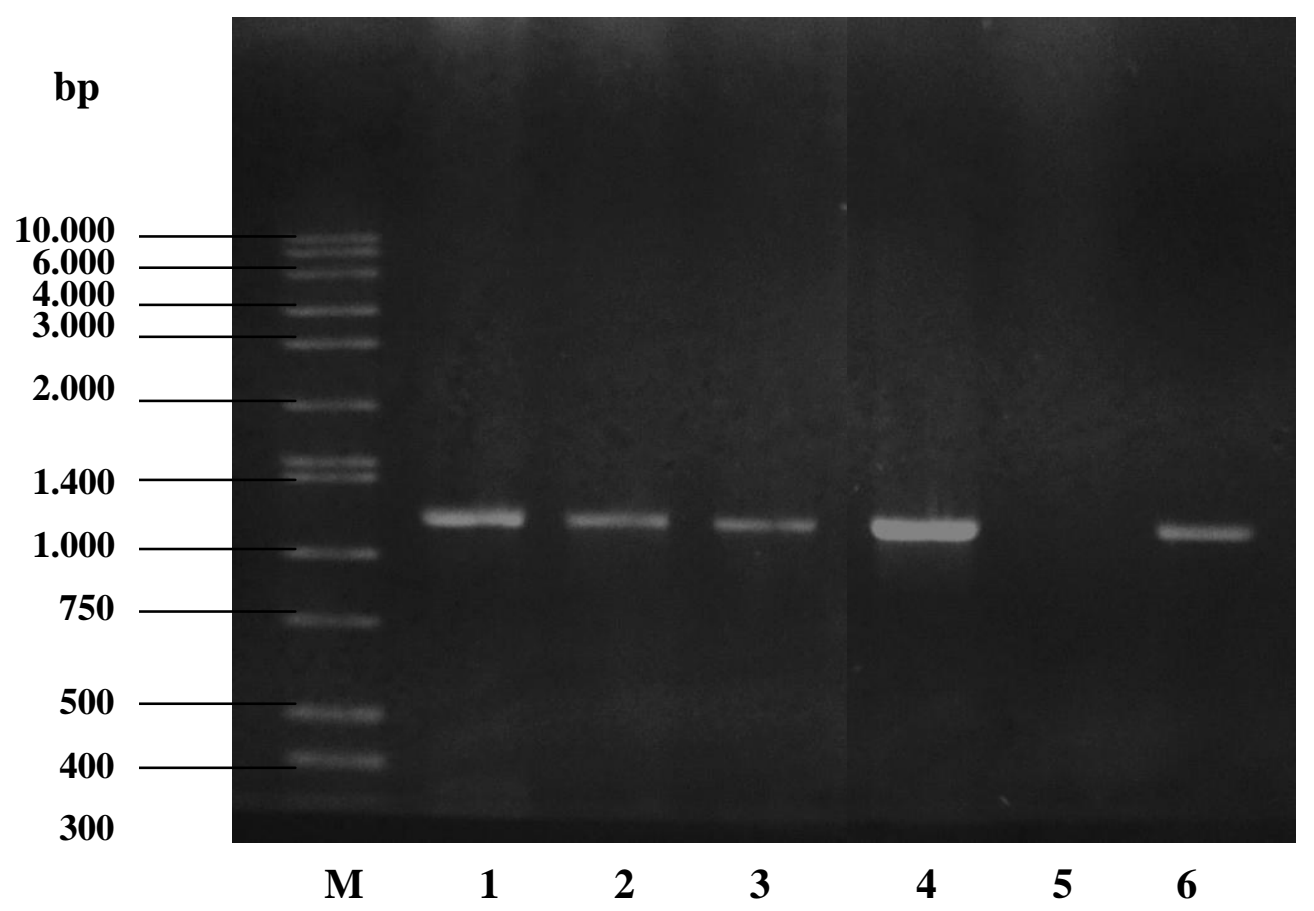

Gambar 4. Hasil elektroforesis plasmid rekombinan pada gel agarose 1\%

Keterangan: M: Marker, 1: DNA takizoit $T$. gondii yang diamplifikasi dengan primer M3F1 dan M3R1 (kontrol positif) (Dewi, 2006), 2: DNA takizoit $T$. gondii yang diamplifikasi dengan primer M3F3 dan M3R3, 3: DNA takizoit $T$. gondii yang diamplifikasi dengan primer M3F3 dan M3R3 yang dipotong dengan EcoRV dan HindIII, 4: pET-M3 yang diamplifikasi dengan M3F3 dan M3R3, 5: pET-32a(+) diamplifikasi dengan M3F1 dan M3R1 (kontrol negatif), 6: DNA rekombinan pET-M3" (DNA rekombinan dengan HindIII pada forward primer dan EcoRV pada reverse primer) yang diamplifikasi dengan M3F1 dan M3R1. 


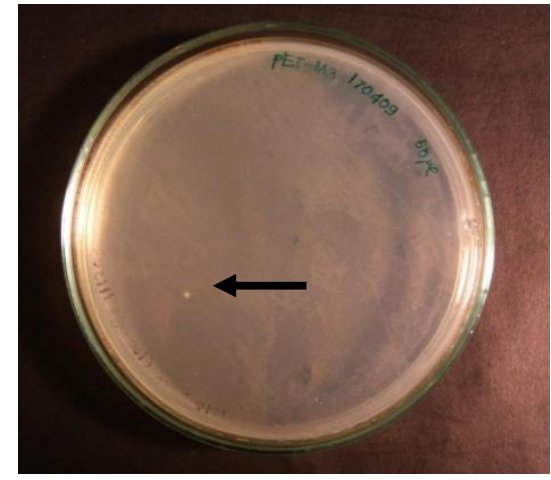

Gambar 5. Koloni yang diduga bakteri rekombinan E. coli BL21

(Ket.: tanda panah menunjukkan koloni putih)

Analisis plasmid rekombinan hasil isolasi dilakukan dengan metode PCR menggunakan primer spesifik M3F3 dan M3R3 dan selanjutnya dielektroforesis menggunakan gel agarose $1 \%$. Hasil amplifikasi dikatakan positif bahwa plasmid tersebut merupakan rekombinan yaitu pita hasil elektroforesis akan sama dengan kontrol positif. Pada Gambar 4 menunjukkan hasil kloning gen insert mic 3 ke dalam vektor pET-32a(+). Hasil rekombinasi gen mic3 dengan pET-32a(+) selanjutnya disebut pET-M3 dengan ukuran kurang lebih $7100 \mathrm{bp}$.

Sekuensing gen mic3 pada pGEMT (yang digunakan sebagai kontrol positif pada penelitian ini) telah dilakukan oleh Dewi (2006) dan dianalisis dengan program BLAST. Alignment sekuen pWTA-M3 yang disekuensing menggunakan primer pUC/M13 forward menunjukkan homologi dengan gen MIC3 isolat $\mathrm{RH}$ dari basa ke-676 sampai dengan basa ke1164 sebesar 97\%. Sekuen yang diperoleh dengan menggunakan primer pUC/M13 reverse menunjukkan homologi dari basa ke-1387 sampai dengan basa ke-1833 sebesar $98 \%$.

Gen mic3 isolat RH sepanjang 2247 bp juga telah disekuensing (kode: AJ132530) (www.ncbi.com; GarciaRéquet et al., 2000). Primer M3F3 menempel dari basa 666-692 dan M3R3 menempel dari basa 1812-1833; kedua primer ini mengapit coding region dan mengamplifikasi gen penyandi MIC-3 sebesar 1170 bp (basa 666-1833).

\section{KESIMPULAN DAN SARAN Kesimpulan}

Penelitian ini berhasil melakukan subkloning gen mic3 hasil amplifikasi gen mic3 T. gondii isolat lokal, sebesar $1,2 \mathrm{kbp}$ ke vektor pET-32a(+) pada $E$. coli BL-21.

\section{Saran}

Klon spesifik yang telah diperoleh selanjutnya diekspresikan dan protein rekombinan yang dihasilkan dapat dipelajari imunogenitasnya serta diharapkan dapat dipakai untuk berbagai keperluan, diantaranya sebagai kandidat vaksin serta pengembangan perangkat diagnosis toksoplasmosis.

\section{UCAPAN TERIMA KASIH}

Ucapan terima kasih ditujukan kepada semua pihak yang telah membantu dalam penelitian ini. PAU UGM Yogyakarta, Prof. Dr. drh. Wayan T. Artama selaku promotor, Dr. drh. Aris Haryanto, M. Si., Dr. Nastiti Wijayanti, S.Si., .M.Si., Ibu Arsiah, Bpk. Jono, Bpk. Haryanto, Ibu Tri, Bpk. Jo, Bpk. Toni, Ibu Ika. Toxo team: Pupung, Etty, Yuli, Dyah, Hevi, Ibu Sorta, Ibu Win, dan Lita.

\section{DAFTAR PUSTAKA}

Beghetto, E., Buffolano, W., Spadoni, A., Del Pezzo, M., Di Cristina, M., Minenkova, O., Petersen, E., Felici, F., Gargano, N. 2003. Use of an Immunoglobulin $\mathrm{G}$ Avidity Assay Based on Recombinant Antigens for Diagnosis of Primary Toxoplasma gondii Infection during Pregnancy. Journal of Clinical Microbiology. 41(12): 5414-5418. 
Beghetto, E., Nielsen, H. V., Del Porto, P., Buffolano, W., Guglietta, S., Felici, F., Petersen, E., Gargano, N. 2005. A Combination of Antigenic Regions of Toxoplasma gondii Microneme Proteins Induces Protective Immunity against Oral Infection with Parasite Cysts. The Journal of Infectious Disease. 191: 637-645.

Black, M.W. and Boothroyd, J. C. 2000. Lytic Cycle of Toxoplasma gondii. Microbiology and Molecular Biology Reviews. 64 (3): 607-623.

Buffolano, W., Beghetto, E., Del Pezzo, M., Spadoni, A., Di Cristina, M., Petersen, E., Gargano, N. 2005. Use of Recombinant Antigens for Early Postnatal Diagnosis of Congenital Toxoplasmosis. Journal of Clinical Microbiology. 43(12): 5916-5924.

Brown, T.A. 1991. Pengantar Kloning Gena. Cetakan pertama. Terjemahan dari Gene Cloning an Introduction. Editor Muhammah, S.A. dan Praseno. Penerbit Yayasan Essentia Medica. Yogyakarta. 3-9, 32-33, 62-65, 218-235.

Carruthers, V.B. 2004. Proteases as Potential Targets for Blocking Toxoplasma gondii Invasion ang Replication. In: In: Opportunistic Infections: Toxoplasma, Sacocystis, and Microsporidia. Kluwer Academic Publishers. New York. 21-38.

Dewi, N.N.D. 2006. Kloning Gen Penyandi Protein Mikronema 3 (MIC3) Takizoit Toxoplasma gondii Isolat Lokal. Thesis. Program Studi Bioteknologi Universitas Gadjah Mada, Yogyakarta.
Gandahusada, S. 1995. Penanggulangan Toksoplasmosis dalam Meningkatkan Kualitas Sumber Daya Manusia. Majalah Kedokteran Indonesia. 45 (6) : 365370.

Garcia- Réquet, N., Lebrun, M., Fourmaux, M., Mercereau-Puijalon, O., Taramann, Beckers, J.M., Samyn, B., Van Beeumen, J., Bout, D., Dubremetz, J. 2000. The Microneme Protein MIC3 of Toxoplasma gondii is a Secretory Adhesin that Binds to Both the Surface of the Host Cells and the Surface of the Parasit. Cellular Microbiology. 2 (4): 353-364.

Glick, B.R., Pasternak, J.J. 1994. Molecular Biotechnology. Principles and Applications of Recombinant DNA. ASM Press, Washington DC. 17-33.

Ismael, A.B., Sekkai, D., Collin, C., Bout, D., Mévélec, M. 2003. The MIC3 Gene of Toxoplasma gondii is a Novel Potent Vaccine Candidate against Toxoplasmosis. Infection and Immunity. 71 (11): 6222-6228.

Novagen. 2006. pET system manual. 11 th ed. www.novagen.com. Diakses tanggal 13 Agustus 2007.

Old, R. W. and Primrose, S. B. 2003. Prinsip-prinsip Manipulasi Gen. Suatu Pengantar Rekayasa Genetik. Edisi Keempat. Penerjemah: Susilo, H. dan Corebima, A. D. Penerbit Universitas Indonesia. 145-170.

Sambrook, J. and Russel, D.W. 2001. Molecular Cloning. A Laboratory Manual. Third Edition. Cold Spring Harbor Laboratory Press. New York. 3: A8. 20 
Terazawa, A., Muljono, R., Susanto, L., Margono, S.S., Konishi, E. 2003. High Toxoplasma Antibody Prevalence among Inhabitants in Jakarta, Indonesia. Jpn. J. Infect. Dis. 56: 107-109.

Wihadmadyatami, H. 2009. Kajian Serologis Toksoplasmosis pada Sapi dengan Metode Enzyme
Linked Immunosorbent Assay Menggunakan Protein Rekombinan GRA-1. Tesis. Program Studi Sains Veteriner. Universitas Gadjah Mada. Yogyakarta

www.ncbi.com. Diakses tanggal 15 Agustus 2007. 